\title{
EKSOTIKA SUKU MENTAWAI
DALAM FOTOGRAFI DOKUMENTER
}

\section{journat of phictogrupry. irts, ordo' s,Asoles}

Volume 2 Nomor 2,
Rindha Mita Purwaningsih

Pamungkas Wahyu Setiyanto

Oscar Samaratungga

Fakultas Seni Media Rekam

Institut Seni Indonesia (ISI) Yogyakarta

Surel: mitarindha@gmail.com

\begin{abstract}
Abstrak
Objek penciptaan karya fotografi membahas eksotika kegiatan sehari-hari suku pedalaman Mentawai, Siberut Selatan. Penciptaan karya didasari oleh minimya informasi tentang keseharian masyarakat pedalaman dusun Buttui dan diciptakan karya ini, diharapkan mampu memberi gambaran dan informasi tentang kehidupan para suku pedalaman di Mentawai melalui fotografi dokumenter. Penciptaan karya fotografi ini berorientasi dengan eksotika kegiatan sehari-hari suku Mentawai sebagai dasar acuan proses penciptaan dengan metode observasi,eksplorasi, pemotretan. Karya foto dibuat dalam fotografi dokumenter, dengan mengambil peristiwa-peristiwa yang menarik lewat bidang jurnalistik. Suatu cara pandang baru dan inspiratif bagi yang melihat dan merasakan dapat membuka mata kita seutuhnya tentang lingkungan budaya di sekitar kita yang mulai terkikis oleh kerasnya kemajuan dan ketatnya perkembangan zaman.
\end{abstract}

Kata kunci: eksotika, suku Mentawai, fotografi dokumenter

\begin{abstract}
Exotica of Mentawai Tribe in Documentary Photography. This abstract discusses the daily exotica of object creation in the heart of Mentawai, South Siberut. This work, with a lack of source information, is based on the daily lives of rural people in Buttui village. It is created with the hopes of capturing and giving information about the tribe lives in rural Mentawai through documentary photography. This abstract is oriented in Mentawai tribe as a basis creation process using observation, exploration, and experimental methods. The photographs are made with documentary photography that captures enticing events through journalism. A new perspective and inspirationwill completely open people's eyes, for those who see and feel, on the nowadays cultural environment which slowly eroded by the rough progress and tight developmental era.
\end{abstract}

Keywords: exotica, Mentawai tribe, documentary photography 


\section{PENDAHULUAN}

Sebagai negara kepulauan, Indonesia memiliki lebih dari 1500 suku bangsa dan setidaknya memiliki 1027 bahasa. Berbicara tentang keberagaman suku, di Sumatera Barat ada sebuah suku kuno yang menempati Kepulauan Mentawai yang dikenal dengan Suku Mentawai. Suku Mentawai merupakan suku pedalaman yang menghuni pulau-pulau di Mentawai.

Hingga saat ini, Suku Mentawai banyak dijadikan sebagai bahan penelitian oleh para peneliti, yang bertujuan untuk memahami bagaimana pola hidup dan pola interaksi dari suku di bagian barat Indonesia ini. Beberapa peneliti berpendapat bahwa Suku Mentawai berasal dari ras polinesia, namun ada juga yang meyakini bahwa suku ini berasal dari ras Proto Malaya alias suku Melayu Tua.

Mentawai merupakan kepulauan yang terdiri dari beberapa puluh pulau kecil, dengan empat pulau besar yakni Pulau Siberut, Pulau Pagai Utara, Pagai Selatan, dan Pulau Sipora (Harian Kompas, 2015). Pulau yang terbesar adalah Pulau Siberut. Ibu kota Kabupaten Kepulauan Mentawai berkedudukan di Tuapejat, Pulau Sipora (Gagas, 2013).

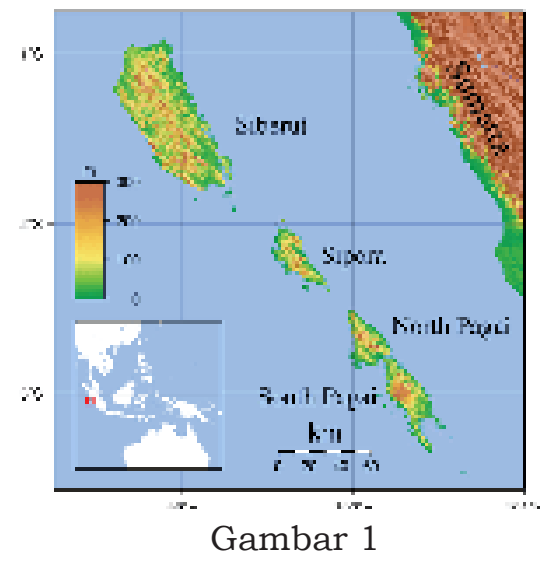

Peta Kepulauan Mentawai Sumber: https://sains.kompas.com/ $\mathrm{read} / 2015 / 06 / 28 / 16300061 /$ Peta.Bawah.Laut. Mentawai.Tuntas.Patahan.Aktif.Ditemukan (diakses 8 April 2018 pukul 13.00 WIB).
Kabupaten Kepulauan Mentawai merupakan salah satu Kabupaten di Propinsi Sumatera Barat dengan posisi geografis yang terletak diantara 0055'00" - 3021'00" Lintang Selatan dan 98035'00" - 100032'00" Bujur Timur dengan luas wilayah tercatat $6.011,35 \mathrm{~km} 2$ dan garis pantai sepanjang 1.402,66 km. Secara geografis, daratan Kabupaten Kepulauan Mentawai ini terpisahkan dari Propinsi Sumatera Barat oleh laut, yaitu dengan batas sebelah Utara adalah Selat Siberut, sebelah Selatan berbatasan dengan Samudera Hindia, sebelah Timur berbatasan dengan Selat Mentawai, serta sebelah Barat berbatasan dengan Samudera Hindia (M.Gulit Agung W, Eni Purwaningsih, Lucky Zamzami, 2014).

Suku Mentawai adalah suku yang unik. Setelah diteliti, ternyata Suku Mentawai adalah suku tertua di Indonesia. Para peneliti meyakini bahwa nenek moyang dari Suku Mentawai sudah mendiami lokasi Kepulauan Mentawai di barat Sumatera ini sejak tahun 500 SM.

Suku Mentawai merupakan suku yang memiliki agama dan kepercayaan tersendiri. Kepercayaan yang dianut oleh suku ini dikenal dengan nama Sabulungan. Sabulungan adalah suatu kepercayaan terhadap seluruh benda yang memiliki roh dan jiwa. Ketika roh tidak dapat dirawat dengan baik, maka roh ini akan bergentayangan dan menyebabkan kesialan serta juga menyebabkan munculnya wabah penyakit.

Unsur-unsur yang kuat dalammenyatukan kebudayaan setiap rakyat adalah adat. Adat atau "Arat" dalam bahasa dan kebudayaan Mentawai mencakup berbagi macam hal yang digolongkan kepada tradisi. Tradisi nenek moyang mutlak harus diterima tanpa gugatan, karena telah diperjuangkan dari 
masa ke masa, yang mendarah daging dalam kehidupan masyarakat selama bertahun-tahun. Oleh sebab itu, Arat menjadi norma kehidupan bagi manusia, baik secara pribadi maupun dalam keluarga dan suku. Arat merupakan warisan suci, karena semenjak dahulu ditemukan oleh nenek moyang, dan kelestariannya harus dijaga dengan baik.

Memang Arat menjadikan orang Mentawai menjadi konservatif, namun hal yang demikian tidak dapat mencabut akar kebebasan dalam kehidupan, malah tetap menghormati dan menjunjung tinggi martabat manusia. Setiap perbuatan yang baik senantiasa sesuai dengan Arat. Tingkah laku yang bertentangan denganArat dianggap dosa. Sesuatu yang belum pernah berlaku, dianggap kejahatan. Mentaati Arat berarti merelakan diri dibimbing oleh tradisi, yang menjadi ukuran prima dalam setiap moralitas.

Arat dijadikan landasan pokok dan norma dalam penentuan segalanya, baik manusia, binatang, fenomena natural (gejala alamiah), dan rentetan waktu. Garis besar haluan hidup berpedoman kepada Arat, dan Aratlah yang langsung mengaturnya. Arat bagi masyarakat Mentawai adalah sebuah keselarasan dengan dunia, pemersatu dengan Uma dan jaminan hidup yang penuh dengan kedamaian dan ketentraman.

Masyarakat Mentawai bersifat patrinial (adat masyarakat yang mengatur alur keturunan berasal dari pihak ayah) dan kehidupan sosialnya dalam suku disebut "uma". Struktur sosial tradisional adalah kebersamaan, mereka tinggal di rumah besar yang disebut juga "uma" yang berada di tanah-tanah suku.

Seluruh makanan, hasil hutan dan pekerjaan dibagi dalam satu uma. Kelompok-kelompok patrinial ini terdiri dari keluarga-keluarga yang hidup di tempat-tempat yang sempit di sepanjang sungai-sungai besar. Walaupun telah terjadi hubungan perkawinan antara kelompok-kelompok uma yang tinggal di lembah sungai yang sama, akan tetapi kesatuan-kesatuan politik tidak pernah terbentuk karena peristiwa ini.

Struktur sosial itu juga bersifat egalitarian, yaitu setiap anggota dewasa dalam uma mempunyai kedudukan yang sama kecuali "sikerei" (dukun) yang mempunyai hak lebih tinggi karena dapat menyembuhkan penyakit dan memimpin upacara keagamaan.

Dalam masyarakat Mentawai tidak dikenal akan adanya pembagaian kasta atau golongan serta tidak ada kepemimpinan yang bersifat otoriter dan ahli waris dengan corak kefeodalan. Semua anggota masyarakat memperoleh kedudukan sederajat. Kebiasaan masyarakat Mentawai dalam mencari nafkah hanya membutuhkan waktu relatif singkat, sedangkan waktu selebihnya digunakan untuk pesta-pesta yang bisa mempererat tali persaudaraan. Dalam mencari nafkah mereka tidak secara berlebihan tetapi secukupnya saja.

Namun, jika dilihat dari salahsatu hasil kebudayaan yang dimiliki oleh suku Mentawai, yaitu tato, bisa dikatakan bahwa dalam suku Mentawai terdapat tingkatan kelas. Hal itu disebabkan suku Mentawai telah mengenal tato sebagai penanda strata kelas.

Fenomena suku Mentawai menarik untuk dijadikan karya seni fotografi dokumenter, karena melalui media foto bisa mengkomunikasikan kepada masyarakat umum atau khalayak tentang eksotika kehidupan sehari-hari suku pedalaman Mentawai dengan menggunakan teknik EDFAT. Teknik EDFAT yaitu pemotretan 
dengan objek foto dengan long shoot dan angle tertentu, pengambilan gambar yang terfokus pada bagian kecil dan penting, pembingkaian photo shot sebagai aspek estetis, sudut pengambilan pemotretan atau sisi pandang, dan waktu kecepatan rana.

Menurut Feininger (1996), fotografi adalah bahasa gambar, hasil terakhir dari bentuk tertua komunikasi percetakan. Tujuan yang hakiki dari fotografi ini adalah komunikasi.Foto merupakan salah satu media komunikasi yang bisa digunakan untuk menyampaikan pesan atau ide kepada orang lain. Foto atau fotografi merupakan sebuah media yang bisa digunakan untuk mendokumentasikan suatu momen atau peristiwa penting. Fotografi dapat menguak kembali kenangan demi kenangan terdahulu dan mempunyai nilai dokumentasi yang tinggi karena mampu merekam sesuatu yang tidak mungkin kembali.

Fotografi dokumentasi bertujuan merekam kejadian-kejadian penting, baik untuk kepentingan pribadi atau kepentingan instansi, dalam gambargambar foto (Sundardi, 1979). Melalui foto dokumentasi, kenyataan yang terjadi dapat diwakilkan dan dapat terungkap dengan bahasa visual dua dimensi.

Fotografi dokumenter merupakan sarana yang paling tepat dalam penyampaian informasi yang penting dan perlu untuk diketahui oleh banyak orang. Karya foto dokumenter dapat menampilkan realita yang ditampilkan pada kehidupan suku Mentawai. Pembuatan fotografi dokumenter harus tetap mempertimbangkan hal-hal yang berhubungan dengan objek foto dan teknik pemotretan. Foto dokumenter baru bisa dikatakan baik jika hasilnya bukan hanya sekedar menggambarkan suatu kejadian secara terang dan jelas, namun juga mampu merekam nuansa suatu peristiwa. Foto dokumenter yang baik harus dapat menceritakan keseluruhan acara, mulai dari proses persiapan, puncak acara, sampai penutupannya (Sugiarto, 2006).

Ide penciptaan berawal dari bulatnya nita untuk menunjukkan kehidupan sehari-hari Suku Pedalaman Mentawai dalam bentuk fotografi dokumenter dan mengulas jenis teknik yang mungkin digunakan dalam memvisualisasikan kehidupan sehari-hari Suku Pedalaman Mentawai.

Penciptaan karya fotografi dengan judul eksotika suku Mentawai dalam fotografi dokumenter bertujuan untuk mengeksplorasi suku Mentawai dengan menggunakan media fotografi dan eksplorasi teknik fotografi dalam karya fotografi documenter dan menerapkan teknik fotografi dokumenter dengan metode EDFAT (Entire, Detail, Frame, Angle, Time) pada visualisasi eksotika Suku Mentawai, menggunakan gambar atau foto secara sistematik serta menganalisis hasil foto.

Penciptaan karya fotografi dengan judul eksotika suku Mentawai dalam fotografi dokumenter diharapkan dapat menyampaikan informasi dalam bentuk visual pada masyarakat secara umum, karya fotografi ini bisa menjadi inspirasi mahasiswa/i yang ingin mengunjungi suku pedalaman di Mentawai dan menambah keberagaman penciptaan karya seni fotografi dalam lingkup akademik jurusan Fotografi, Fakultas Seni Media Rekam, Institut Seni Indonesia Yogyakarta.

Di dalam penciptaan sebuah karya fotografi, konsep penciptaan atau penentuan tema adalah dasar yang sangat penting. Konsep penciptaan atau ide yang lahir karena adanya pengalaman estetis yang dialami seseorang. Pengalaman estetis ini biasanya dipengaruhi oleh faktor 
lingkungan dan faktor itu datang dari dalam dan luar dirinya. Berdasarkan dua faktor inilah ekspresi setiap orang akan sangat berbeda dalam memvisualkan kenyataankenyataan di lingkungan tersebut.Faktor lingkungan yang dimaksud adalah pada lingkungan yang berbeda pada kehidupan atau kebiasaan masyarakat kota dan masyarakat suku pedalaman itu sendiri. Dari faktor tersebut, timbullah pembuatan karya seni yang didapat dari fenomena yang terjadi dari dalam diri.

\section{Fotografi Dokumenter}

Pendekatan foto dokumenter akan digunakan dalam penelitian dan penciptaan ini. Genre foto dokumenter dianggap tepat untuk merefleksikan objek karena foto dokumenter menyajikan fotofoto secara jelas tanpa adanya rekayasa, bisa langsung bercerita tentang objek yang dimaksud sehingga diharapkan penikmat foto bisa ikut merasakan sebuah fenomena seperti apa adanya. Ini sedikit berbeda dengan genre esai foto, yang menempatkan opini fotografer dalam posisi yang penting. Demikianlah, fotografi dokumenter harus menyampaikan kebenaran. Buku TimeLife Books memberi pengertian tentang foto dokumenter sebagai "A depiction of the realworld by photographer whose intent is to communicate something of importanceto make a comment-that will be understood by viewer." (The Editor of Time Life Book, 1973). Selain itu, dalam buku yang lain disebutkan bahwa:

Documentary photography has also created important records that provide tangible evidence supported by great visual detail, cast the compelling impression of truth, allow viewers to occupy the position ofthe photographer, serve as an impartial and faithful witness to life's events, and freeze aninstant of time so that places and events may belater studied and restudied (Peres, 2007).

\section{Metode EDFAT}

Metode EDFAT di dalam lingkungan akademisi belum sering digunakan, namun sudah sangat dikenal dan diterapkan di lingkungan profesional khususnya bagi para wartawan atau pewarta foto baik skala nasional maupun internasional. Tidak banyak sumber pustaka yang menjelaskan metode EDFAT. Kebanyakan pernyataan tentang EDFAT dituliskan tanpa menyertakan sumbernya. Eddy Hasby dalam (Irwandi \& Pamungkas Wahyu, 2017) menguraikan kelima aspek EDFAT sebagai berikut.

\section{$E=$ Entire}

Dikenal juga sebagai 'established shot', suatu keseluruhan pemotretan yang dilakukan begitu melihat suatu peristiwa atau bentuk penugasan lain.

\section{D= Detail}

Suatu pilihan atas bagian tertentu dari keseluruhan pandangan terdahulu (entire). Tahap ini adalah suatu pilihan pengambilan keputusan atas sesuatu yang dinilai paling tepat sebagai "point of interest'. Detail: Pengambilan gambar yang terfokus pada bagian kecil dan penting.

\section{$F=$ Frame}

Suatu tahapan saat mulai membingkai suatu detil yang telah dipilih. Fase ini mengantar seorang calon foto jurnalis mengenal arti suatu komposisi, pola, tekstur dan bentuk subjek pemotretan dengan akurat. Rasa artistik semakin penting dalam tahap ini.

\section{A=Angle}

Tahap ketika sudut pandang menjadi dominan, ketinggian, kerendahan, level mata, kiri, kanan dan cara melihat. Fase ini penting mengonsepsikan aspek 
visual apa yang diinginkan. Angle: sudut pengambilan pemotretan atau sisi pandang. T=Time

Tahap penentuan waktu penyinaran dengan kombinasi yang tepat antara diafragma dan kecepatan atas keempat tingkat yang telah disebutkan sebelumnya. Pengetahuan teknis atas keinginan membekukan gerakan atau memilih ketajaman ruang adalah satu prasyarat dasar yang sangat diperlukan.

Supaya proses penciptaan karya memiliki acuan visual yang dapat membantu visualisasi dari ide dan konsep yang akan dirancang, berikut ini adalah beberapa fotografer dengan karya-karya yang menjadi acuan:

Gambar 2 adalah hasil karya dari dr. Paul Wirz yang menggambarkan kehidupan suku pedalaman Mentawai yang sedang menari Turuk Laggai. Turuk Laggai merupakan tarian yang gerakannya adalah peniruan dari gerak-gerik binatangbinatang di alam sekitar masyarakat suku Mentawai (Alexander Dolfvovic Hivtomath Tlerukova, 2010). Karena kedekatan suku Mentawai dengan alam, maka gerakan dan tingkah laku binatang-binatang tersebut dituangkan dalam tarian. Dari hasil karya ini, sang fotografer telah menerapkan fotografi dokumenter pada suku pedalaman Mentawai, yang nantinya akan dijadikan acuan untuk penciptaan karya foto dokumenter eksotika suku Mentawai, karena pada foto tersebut tidak adanya settingan dalam foto sehingga yang ditampilkan akan terlihat lebih nyata apa adanya pada lokasi pemotretan.

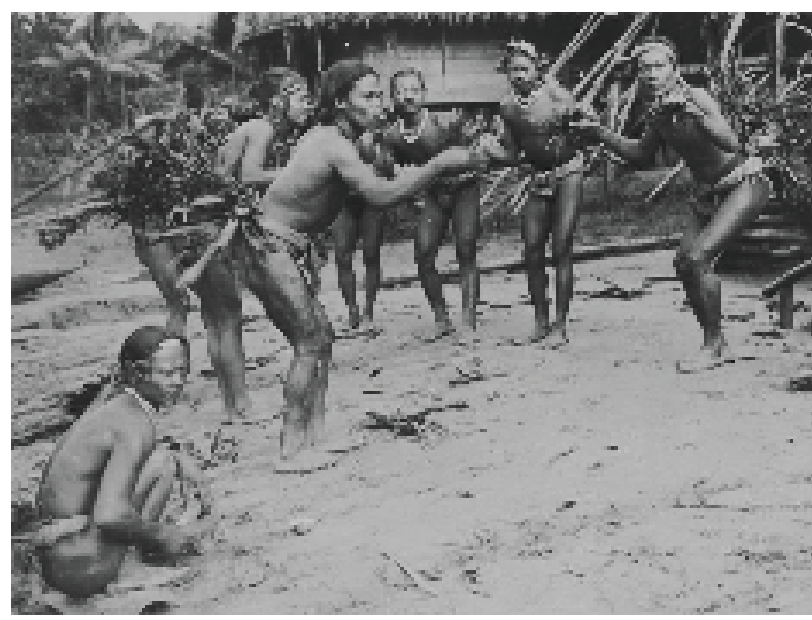

Gambar 2

Tinjauan Karya 1: "Generasi Terakhir" Fotografer: dr. Paul Wirz

Sumber: http://metalsuck.blogspot. co.id/2010/08/ (diakses pada 20 April 2018, pukul 18.00 WIB)

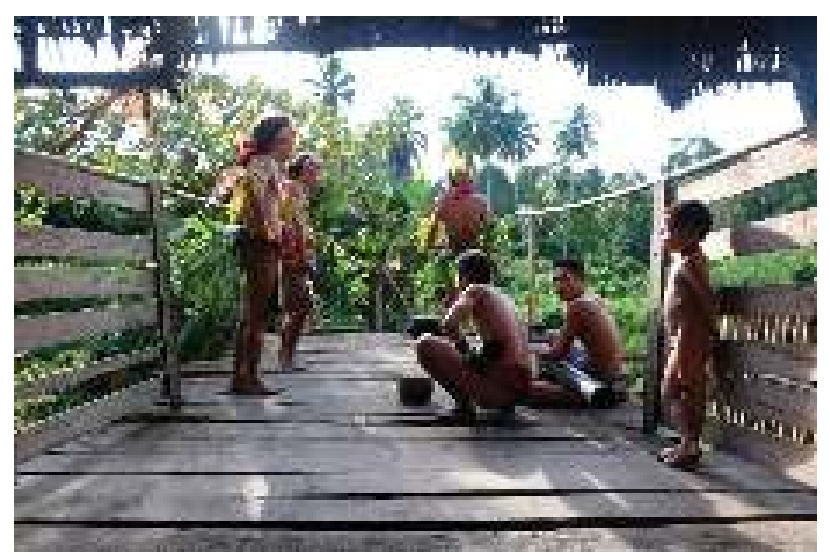

Gambar 3

Tinjauan Karya 2: "bersiap-siap berburu" Fotografer: Harival Zayuka

Sumber: http://harivalzayuka.com/ (diakses pada 5 Mei 2018, pukul 20.35 WIB)

Berburu merupakan sebuah aktivitas kebanggaan kaum laki-laki Mentawai. Kebanggaan tersebut dapat dilihat dari pajangan tengkorak binatang buruan (abakmanang) di dalam uma. Selain sebagai ajang menguji keahlian dan ketrampilan menggunakan peralatan berburu juga menjadi sebuah bentuk pengetahuan tradisional masyarakat adat Mentawai terhadap alam dan fenomenanya. Sebab berburu tidak dilakukan setiap saat, ada masa atau waktu tertentu yang dianggap baik untuk berburu. 


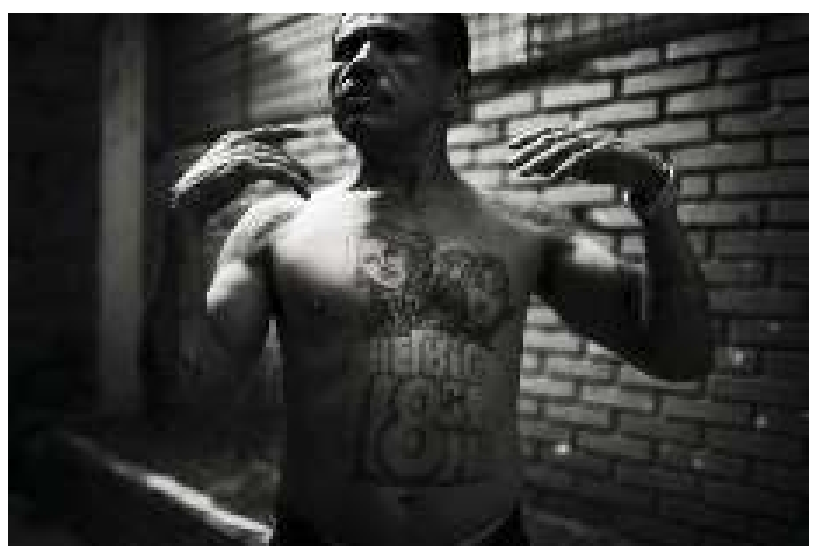

Gambar 4

Tinjauan Karya 4: "latidoamerica" Fotografer: Javier Arcenillas

Sumber: https://www.worldpressphoto.org/ collection/photo/2018/long-term-projects / javier-arcenillas(diakses pada 22 Juli 2018, pukul 02.43 WIB).

Karya foto Harival Zayuka (Zayuka, 2017) (gambar 3) nantinya akan dijadikan tinjauan karena pada foto tersebut tidak diarahkan untuk berpose, sehingga terlihat natural dan tidak dibuat-buat. Karena penciptaan karya fotografi ini lebih mengutamakan visual kegiatan sehari-hari pada suku Mentawai.

Perbedaan untuk hasil akhir nantinya akan berbeda dengan tinjauan karya tersebut, karena dari objek foto, lokasi, teknik foto dan angle foto akan berbeda.

Gambar 4 karya Javier Arcenillas nantinya akan menjadi acuan hasil karya akhir penciptaan karya seni, karena pada foto tersebut menggunakan warna hitam putih. Hitam putih merupakan pilihan foto yang menampilkan satu nada warna yang mencakup gradasi dari hitam, abu-abu, hingga putih. Tinjauan karya ini mengacu pada hasil karya dari Javier Arcenillas yang berasal dari Bilbao, Spanyol.

Dia adalah seorang psikolog di Universitas Complutense Madrid. Javier juga mengajarkan fotografi jurnalistik dan dokumenter di International School PICA. Fotografer tersebut menggunakan warna hitam putih sebagai hasil karya foto, selain itu Javier Arcenillas juga sebagai pemenang Long-Term Project Third prize stories pada World Press Photo tahun 2018 (Arcenillas, 2012).

Kesimpulan dari tinjauan karya tersebut adalah karya yang akan dibuat nantinya berwarna hitam putih, karena hitam dan putih dibuat dengan sebuah alasan kesederhanaan. Di dalamnya terdapat spektrum nonkromatik tonal yang dapat mengurangi warna bias untuk pola hitam, putih, dan abu-abu sehingga dapat mengungkapkan elemen tekstur, garis, bentuk dan cahaya. Sehingga dapat disimpulkan bahwa dengan menggunakan tampilan hitam putih, maka warna-warna pada spektrum warna dapat dikurangi sehingga elemen dari tekstur, garis, bentuk, cahaya, dan kecerahan yang dihasilkannya akan cenderung tidak sama dan kejelasan warnanya terlihat lebih sederhana. Penciptaan karya fotografi ini ingin memunculkan warna hitam putih yang memiliki nilai artistik yang kuat, dan dramatis pada foto eksotika suku Mentawai.

\section{Metode Penciptaan}

1. Observasi

Observasi merupakan salah satu metode pengumpulan data dalam penelitian kualitatif, yaitu melakukan penelitian langsung menuju ke lapangan dengan cara mengamati perilaku dan aktivitas individu atau masyarakat di lokasi penelitian.Observasi dilakukan dengan cara hadir dilokasi tempat kegiatan yang sedang diamati, dan terlibat langsung dengan kegiatan yang dilakukan informan. Observasi suku pedalaman Mentawai adalah kegiatan mengamati keseharian mereka dan juga ikut melakukan kegiatan yang dilakukan keluarga Sikerei. 


\section{Eksplorasi}

a. Membangun komunikasi dan hubungan yang baik dengan Sikerei, dan masyarakat Dusun Buttui.

b. Mengeksplorasi lingkungan pedalaman di Dusun Buttui.

c. Pengumpulan data, merupakan bagian yang penting dalam penelitian, pengumpulan data yang dilakukan untuk penciptaan ini adalah observasi, wawancara dan studi pustaka.

3. Pemotretan

a. Pemilihan ISO, International Standards Organization adalah satuan untuk mengukur kepekaan sensor kamera dalam menangkap cahaya.

b. Ruang Tajam (Depth of Field), Ruang tajam atau depth of field adalah wilayah ketajaman gambar yang dapat ditangkap oleh lensa dan terekam pada film atau sensor digital kamera.

c. Pembentukan, Setelah melakukan pemotretan pada objekadalah memilih kembali hasil foto tersebut dan akandiolah dengan menggunakan softwareLightroom dan Photoshop dengan melakukan pengolahan foto sebatas level, contras dan tone tanpa penambahan dan pengurangan unsur-unsur lain.

\section{PEMBAHASAN}

1. Uma (Rumah Adat)

Uma adalah rumah adat suku pedalaman Mentawai, kegunaannya adalah untuk tempat menginap bersama, menyimpan pusaka-pusaka dan benda warisan, penyimpanan tengkorak hasil buruan, pelantikan Sikerei, musyawarah masyarakat, dan tempat untuk persembahan. Selain itu, uma juga digunakan sebagai tempat melakukan upacara adat dan pertemuan kerabat keluarga. Rumah adat ini dihuni oleh secara bersama oleh tiga hingga lima keluarga.

Uniknya, uma dibangun tanpa menggunakan paku, tetapi dipasak dengan kayu yang kokoh serta sistem sambungan silang. Atap uma terbuat dari daun sagu yang sudah tua dan kering berwarna kecoklatan, lalu disusun rapat. Pondasinya ditanam dengan kedalaman sekitar dua meter di bawah permukaan tanah. Pembangunannya biasanya berlangsung selama kurang lebih satu bulan secara bergotong-royong, tergantung dari ukuran umanya tersebut. Uniknya uma ini tidak memiliki pintu dan dibiarkan terbuka. Banyaknya tengkorak binatang terpajang didekat atap pintu masuk teras dan ruang utama uma, serta ada bermacam-macam anyam-anyaman kering.

Tengkorak yang digantung pada sisi atas pintu masuk adalah tengkorak babi peliharaan. Banyaknya tengkorak babi menandakan jumlah pestayang telah digelar di uma tersebut. Sedangkan tengkorak yang digantung di dekat sisi atas pintu ruang utama adalah tengkorak hasil buruan yang dimaksudkan memanggil roh-roh binatang sebangsanya datang ke dalam uma untuk gabung dengan tengkorak lainnya.

\section{Tato}

Pada saat ini, tentunya kita sudah tidak asing lagi dengan hal yang disebut tato. Seni melukis di kulit ini, meskipun sebagian orang memandangnya sebelah mata, sudah menjadi gaya fashion tersendiri bagi sebagian kalangan masyarakat.

Tato tradisional khas Mentawai yang sudah ada sejak zaman logam yakni sekitar tahun 1500 SM - 500 SM. Bahwa keberadaan seni lukis di atas kulit suku Mentawai lahir 
lebih dulu dibandingkan dengan tato Mesir yang baru dimulai pada tahun 1300 SM.

Bagi masyarakat Mentawai, tato merupakan roh kehidupan. Tato melambangkan keseimbangan antara alam dan penghuninya. Motif juga menggambarkan jati diri dan status sosial atau profesi seseorang. Tato seorang Sikerei akan berbeda dengan tato yang berprofesi sebagai pemburu. Pemburu akan ditato dengan gambar binatang tangkapannya, seperti burung, babi, kera. Membuat tato Mentawai memerlukan bahan alami diantaranya adalah kayu karai yang diruncingkan ujungnya atau jarum yang terbuat dari tulang hewan, serta pewarna yang terbuat dari campuran arang tempurung kelapa dan daun pisang, lalu dicampurkan dengan perasan air tebu. Proses pembuatan tato memakan waktu dan diulang-ulang, dan dipastikan akan menimbulkan rasa sakit bahkan menyebabkan efek demam selama seminggu. Tato pada tubuh Sikerei pun mempunyai artinya masing-masing, tato yang di wajah menggambarkan parang, karena dalam berburu perlu membawa parang. Pada bagian tangan atas yang menggambarkan duri rotan, karena simbol dari atap rumah, tempat ayam dan rotan keranjang.

Pada bagian jari tangan menggambarkan mata pancingyang artinya seperti mata pancing untuk mengambil ikan di sungai. Tato pada bagian paha menggambarkan seperti lantai rumah yang terbuat dari kayu, karena lantai rumah di Mentawai membentuk garis-garis yang disusun rapi didalam uma.

Tato pada bagian punggung menandakan tulang punggung keluarga. Tato bergambar matahari yang terdapat pada bahu artinya dahulu nenek moyang tidak mempunyai jam, jadi selalu melihat ke matahari sebagai patokan menandakan waktu.

Tato bergambar monyet artinya mereka sudah pernah berburu monyet, dan tato bergambar kaki anjing artinya seekor anjing yang selalu menemani berburu ke gunung. Jadi kesimpulan pada tato tersebut, mereka membuat tato tidak sembarangan, semuanya mempunyai arti masing-masing pada setiap bentuk tato tersebut.

\section{Turuk Laggai}

Suku Mentawai dan alam merupakan perpaduan yang tidak terpisahkan. Mulai dari tato, pakaian, bahkan racun untuk tradisi memanah, semuanya dibuat dengan bahan-bahan dari alam.

Turuk Laggai merupakan tarian yang gerakannya adalah peniruan dari gerakgerik binatang di alam sekitar masyarakat suku Mentawai, karena kedekatan suku Mentawai dengan alam itulah, maka gerakan dan tingkah laku binatangbinatang tersebut dituangkan dalam tarian. Selain itu gerakan Turuk Laggai juga menyimpan nilai-nilai luhur yang penting dalam kehidupan suku Mentawai, misalnya perdamaian antar suku.

Turuk Laggai merupakan perpaduan irama hentakan kaki dengan gendang, dan juga disertai dengan nyanyian untuk menggambarkan sebuah cerita yang akan ditirukan disebut Uliat. Uliat adalah sebuah peniruan dari tingkah laku yang akan diperagakan. Turuk Laggai biasanya yang paling sering ditampilkan sebagai bentuk kegembiraan masyarakat dalam hal yang dianggap sebuah kemenangan, kedamaian yang berupa pesta adat dan pesta-pesta kecil lainnya.

\section{Berburu}

Berburu menurut masyarakat suku pedalaman Mentawai adalah pekerjaan 
yang hanya boleh dilakukan oleh kaum pria dan merupakan aktivitas kebanggaan pria. Kebanggaan tersebut dapat dilihat dari pajangan tengkorak binatang buruan (abakmanang) di dalam uma. Selain sebagai ajang menguji keahlian dan keterampilan menggunakan peralatan berburu (busur dan anak panah), berburu juga menjadi sebuah bentuk pengetahuan tradisional masyarakat adat Mentawai terhadap alam dan fenomenanya. Sebab berburu tidak dilakukan setiap saat, ada masa atau waktu tertentu yang dianggap baik untuk berburu, seperti perhitungan bulan. Berburu juga biasanya dilakukan sebagai penutup upacara atau pesta adat (puliaijat). Selain itu setiap kali berburu, berlaku tabu (kei-kei) yang harus dijalani oleh setiap orang yang ikut pergi berburu. Misalnya, tidak boleh makan belut, tidak boleh berhubungan intim dengan istri.

Berburu juga dilakukan dengan upacara panangga yang maknanya sama dengan upacara panaki yaitu meminta izin terlebih dahulu kepada roh-roh penjaga hutan sebagai penghargaan dan rasa terima kasih. Kegiatan berburu di Mentawai ini termasuk pada kegiatan konservasi karena memiliki aturan dan tatacara yang tepat. Perburuan ini dapat membuat populasi hewan yang ada di hutan menjadi sehat karena dilakukan pada waktu-waktu tertentu serta mempertimbangkan ukuran, umur dan satwa-satwa tertentu saja.

Keterampilan membuat dan menggunakan panah beracun merupakan hal yang wajib dimiliki para pria suku pedalaman Mentawai. Mereka sudah berlatih memanah menggunakan bambu sejak kecil. Bahan-bahan untuk meracik racun pada panah yaitu batang ragi, akar tuba, cabe kutu, kulit kayu lappak, dan lengkuas. Semua bahan itu diparut lalu dikeluarkan cairannya dari akar tuba dan kulit kayu lappak dengan ditumbuk. Racun yang sudah jadi ditampung dalam tempurung yang disiapkan menggunakan gelang rotan, kemudian dioleskan ke panah dengan menggunakan kuas yang terbuat dari ekor tupai yang ditancapkan dibambu. Biasanya, panah beracun digunakan untuk berburu rusa, monyet, dan babi. Racun ini mampu membunuh binatang buruan, apabila dosisnya dinaikkan, nyawa manusia pun dapat melayang.

Karya foto 1, Keluarga dari Sikerei Aman Lau Lau (kanan) yang terdiri dari anak pertama nya Aman Telepon beserta istrinya (kedua dari kiri), Aman Godai (kiri) dan istri kedua dari Aman Lau Lau (kedua dari kanan).

Foto dengan karya berjudul 'Keluarga Sikerei' di ambil dengan menggunakan diafragma f/8, speed 1/160 sec, ISO 100, dan focal length $35 \mathrm{~mm}$. Dalam metode EDFAT karya ini masuk kedalam Entire, yaitumemotret secara keseluruhan dari suasana rumah bagian depan keluarga Sikerei. Tujuan menggunakan teknikiniuntuk mencapai visual yang diinginkan. Tujuan utama dalam penciptaan ini diharapkan mampu menggambarkan suasana eksotika dari keluarga Sikerei tersebut.

Pembuatan tato sendiri melewati proses ritual (karya foto 2), karena bagian dari kepercayaan Arat Sabulungan (kepercayaan kepada roh-roh). Bahanbahan dan alat yang digunakan didapat dari alam sekitarnya. Sebelum ada jarum, alat pentatoan yang dipakai adalah sejenis kayu karai, tumbuhan asli Mentawai yang bagian ujungnya diruncingkan. Lalu mulai digambar dan dibentuk menggunakan lidi. Sketsa di atas tubuh itu kemudian ditusuk dengan jarum bertangkai kayu yang dipukul pelan-pelan dengan kayu pemukul untuk memasukkan zat pewarna ke dalam lapisan kulit. Pewarnayang dipakai adalah campuran 
daun pisang dan arang tempurung kelapa dan diberi perasaan air tebu.

Karya berjudul 'Tato Mentawai' menggunakan metode EDFAT karya tersebut masuk ke dalam Detail, yaitu bagian penting yang memfokuskan ke bagian kecil. Tujuan visual tersebut untuk menampilkan keindahan pada tubuh suku Mentawai yang dihias menggunakan tato tradisionalnya.

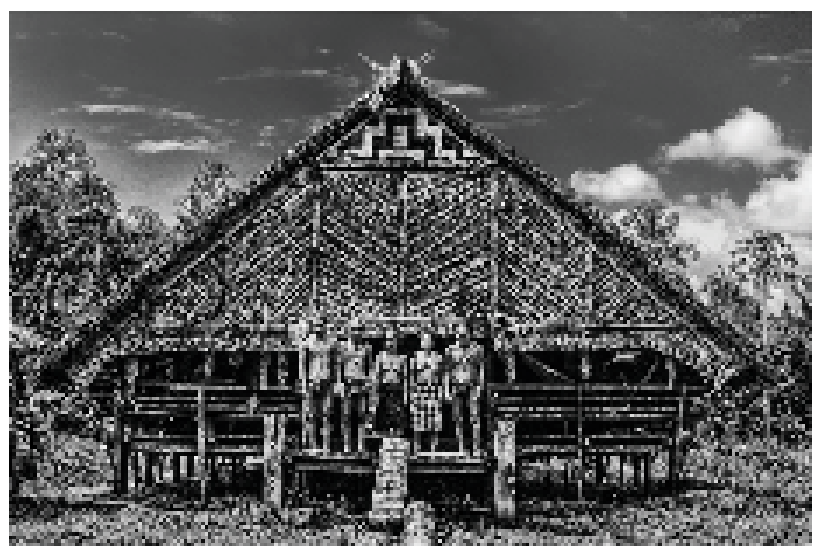

Karya foto 1

Judul karya: Keluarga Sikerei (2018)

Ukuran Karya Foto Tunggal: 40x60 cm Cetak Canvas
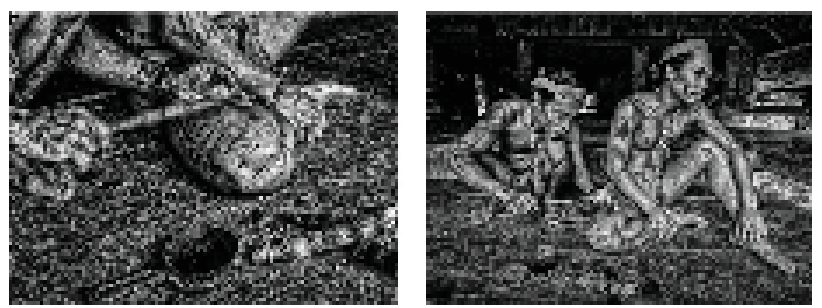

Karya foto 2

Judul karya: Tato Mentawai (2018)

Ukuran Karya Foto Seri: 30x40 cm Cetak Canvas

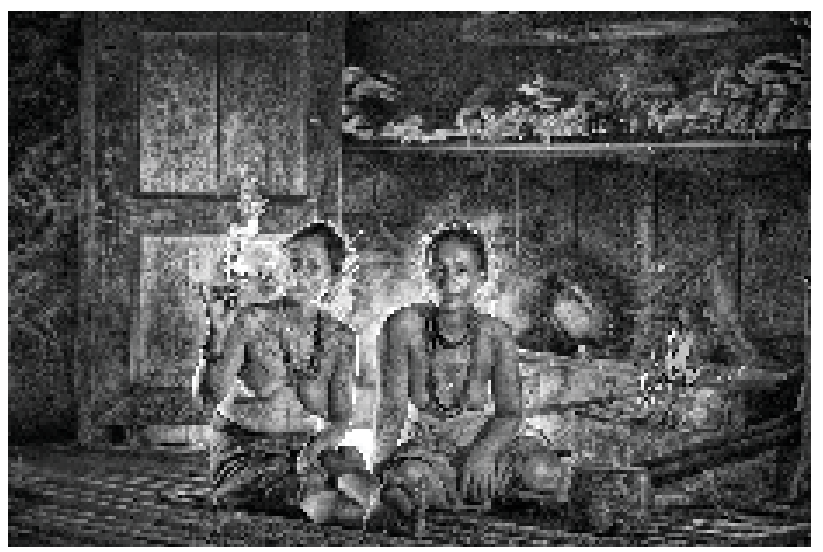

Karya foto 3

Judul karya: Santai (2018)

Ukuran Karya Foto tunggal: 90x60 cm Cetak Canvas
Selain mencari ikan disungai biasanya ibu-ibu paling sering di dapur, beliau memasak, ngobrol, makan, dan hanya sekedar santai-santai. Karena bagi mereka santai di dapur pun sudah menciptakan keharmonisan dalam keluarga Sikerei.

Pada karya berjudul 'Santai' di ambil menggunakan diafragma f/2, speed 1/80, ISO 500, dan focal length $50 \mathrm{~mm}$ dengan ditambahnya flash dari arah belakang dan sisi samping kiri untuk menerangi bagian objek pada aktivitas yang dilakukan pada malam hari. Dalam metode EDFAT karya ini masuk ke dalam Time, kecepatan rana yang dihasilkanpada asap rokok.

Tujuan dari visualisasi ini menggambarkan kentalnya budaya di suku Mentawai terlihat dari perempuan yang tidak memakai pakaian dan juga bertato.

Berburu (karya foto 4) merupakan aktivitas kebanggaan kaum laki-laki pedalaman Mentawai. Kebanggaan tersebut dapat dilihat dari pajangan tengkorak binatang buruan (abakmanang) di dalam uma. Selain sebagai ajang menguji keahlian dan ketrampilan menggunakan peralatan berburu juga menjadi sebuah bentuk pengetahuan tradisional masyarakat adat Mentawai terhadap alam dan fenomenanya. Sebab berburu tidak dilakukan setiap saat, ada masa atau waktu tertentu yang dianggap baik untuk berburu.

Pada karya berjudul 'Berburu' di buat menggunakan diafragma $\mathrm{f} / 2$, speed $1 / 125 \mathrm{sec}$, ISO 100, dan focal length 50 $\mathrm{mm}$. Dalam metode EDFAT karya ini masuk ke dalam Detail, memfokuskan pada benda penting. Peralatan-peralatan dan hasil buruannya. Tujuan dari visualisasinya menggambarkan aktivitas kebanggan pria suku Mentawai. 


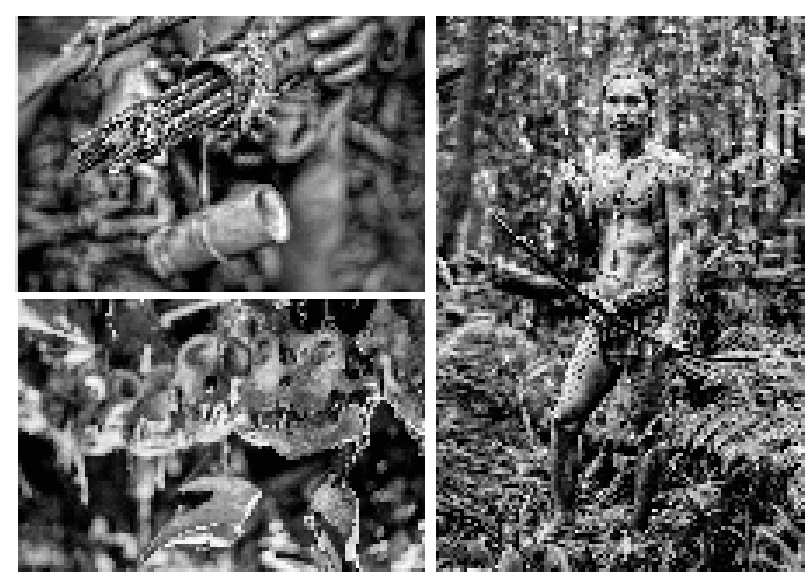

Karya foto 4

Judul karya: Berburu (2018)

Ukuran Karya Foto seri: 50x75 cm, 90x60 cm Cetak Canvas

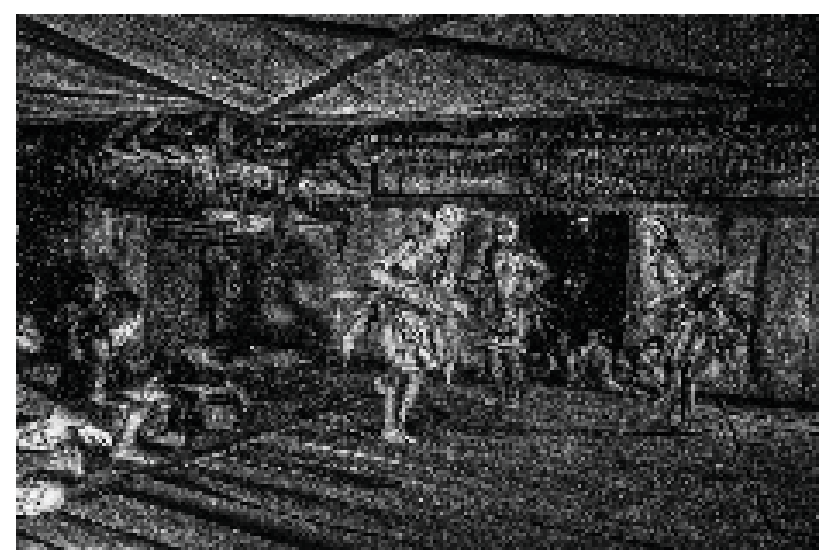

Karya foto 5

Judul karya: Turuk Laggai (2018)

Ukuran Karya Foto tunggal: 40x60 cm Cetak Canvas

Suku pedalaman Mentawai yang sedang menari Turuk Laggai (karya foto 5), Turuk Laggai merupakan tarian yang gerakannya adalah peniruan dari gerakgerik binatang-binatang di alam sekitar masyarakat suku Mentawai. Karena kedekatan suku Mentawai dengan alam itulah, maka gerakan dan tingkah laku binatang-binatang tersebut dituangkan dalam tarian. Tarian ini biasanya disebut dengan Uliat, billow, manyang. Biasanya tarian ini dipersembahkan untuk pembukaan acara-acara penyambutan.

Karya berjudul 'Turuk Laggai' di ambil menggunakan diafragmaf/3.5, speed $1 / 60 \mathrm{sec}$, ISO 3200, dan focal length $20 \mathrm{~mm}$. Dalam metode EDFAT karya ini masuk ke dalam Time, karena waktu yang dipakai untuk membekukan gerakan adalah prasyarat dasar yang diperlukan. Tujuan dari visualisasi ini yaitu mempertahankan dan mencintai kebudayaan Indonesia yang masih bertahan walaupun banyak orang di luar sana yang tidak mengenal kebudayaan negaranya.

Penciptaan karya fotografi ini ingin menghadirkan kehidupan seharihari suku pedalaman suku Mentawai, Sumatera Barat dalam sebuah rangkaian cerita dokumenter dan menjadikan suku pedalaman lebih dekat dengan audiens. Banyak harapan dan keinginan penciptaan karya dalam foto dokumenter ini. Selain memberi suatu cara pandang baru dan inspirasi bagi yang melihat dan merasakan, berharap karya ini dapat membuka mata seutuhnya tentang lingkungan budaya di sekitar yang mulai terkikis oleh kerasnya kemajuan dan ketatnya perkembangan zaman dan berharap untuk lebih mencintai dan menghargai suku terasing, masyarakat terasing, suku pedalaman, dan suku tertinggal sebagai ciri dan jati diri kita sebagai manusia Indonesia seutuhnya.

Melalui media fotografi dokumenter ini penciptaan karya fotografi ini mengajak untuk lebih menghargai apapun yang ada disekitar, yang mungkin luput dari perhatian karena terlena gemerlap indahnya budaya yang tidak jelas arah tujuan dan hakikat yang terkandung di dalamnya.

\section{SIMPULAN}

Objek penciptaan karya fotografi ini adalah jenis fotografi dokumenter yang mengarah pada jenis foto daily life. Penciptaan karya fotografi ini berusaha mengungkap eksotika keseharian dari masyarakat suku Mentawai yang berbeda jauh dari kehidupan kota pada 
umumnya. Foto daily life sendiri mampu menyampaikan pesan tertentu dan mengajak audience melihat kehidupan sehari-hari suku Mentawai sehingga diharapkan mereka juga turut merasakan apa yang dialami pada suku Mentawai oleh objek foto.

Konsep pembuatan karya fotografi ini berorientasi pada satu keluarga Sikerei sebagai acuan kehidupan eksotika dari suku Mentawai, kegiatan para Sikerei sehari-hari dengan cara mempertahankan hidup di hutan.

Karya penciptaan fotografi dokumenter tentang eksotika suku Mentawai dalam proses penciptaannya juga membutuhkan persiapan. Persiapan yang dibuat meliputi pengumpulan data dan mempersiapkan peralatan pemotretan. Pengumpulan data dapat menggunakan beberapa metode seperti, metode observasi di dusun Buttui, Siberut Selatan, metode wawancara dengan keluarga di sana, serta metode pustaka yang membahas tentang suku Mentawai.

Eksotika yang dimaksud adalah mengeksplorasi suku Mentawai menggunakan media fotografi dengan menunjukkan kehidupan sehari-hari suku pedalaman Mentawai. Selain itu juga sebagai keindahan dan keunikan yang dimiliki oleh suku pedalaman Mentawai yang kaya akan budaya, tradisi, dan kebiasaan yang berbeda dengan masyarakat umum.

Eksotika dari kehidupan seharihari suku pedalaman Mentawai dapat ditunjukkan dengan menggunakan media fotografi dan menggunakan eksplorasi teknik fotografi dalam karya fotografi dokumenter. Memudahkan dalam proses penciptaan karya dengan menerapkan teknik fotografi dokumenter dengan menggunakan metode EDFAT.

\section{KEPUSTAKAAN}

Alexander Dolfvovic Hivtomath Tlerukova. (2010). "SUKU MENTAWAI - Suku Kuno Misterius Indonesia yang Akan Hilang". Retrieved August 20, 2004, from http://metalsuck.blogspot. co.id/2010/08/

Arcenillas, J. (2012). "Latidoamerica". Retrieved from https://www. worldpressphoto.org/collection / photo/2018/long-term-projects / javier-arcenillas

Feininger, A. (1996). Unsur Utama Fotografi. Semarang: Eiffhar \& Dahara Prize.

Gagas, U. (2013). Seri Bacpacking \& Traveling - Charming Sumatera Barat. Jakarta: Gramedia Pustaka Utama.

Harian Kompas. (2015). "Peta Bawah Laut Mentawai Tuntas, Patahan Aktif Ditemukan". Retrieved from https: / / sains.kompas.com / read/2015/06/28/16300061/ Peta.Bawah.Laut.Mentawai.Tuntas. Patahan.Aktif.Ditemukan

Irwandi \& Pamungkas Wahyu. (2017). "Foto Dokumenter Bengkel Andong Mbah Musiran: Penerapan dan Tinjauan Metode EDFAT dalam Penciptaan Karya Fotografi”. Jurnal Rekam, Vol 13 No., 32.

M.Gulit Agung W, Eni Purwaningsih, Lucky Zamzami, S. R. (2014). Turuk Sikerei. Lembaga Penerbitan Balitbangkes.

Sugiarto, A. (2006). Cuma Buat yang Ingin Jago Foto. Jakarta: Gramedia Pustaka Utama.

Sundardi, F. (1979). Mari Memotret Menggunakan Kamera Foto. Jakarta: Penerbit Erlangga.

The Editor of Time Life Book. (1973). Life Library of Photography, Documentary Photography. Nederland: Time Life International.

Zayuka, H. (2017). "Sisi Lain dari Suku Pedalaman Mentawai yang Mulai Terkontaminasi”. Retrieved from https://harivalzayuka. com/2017/03/20/sisi-lain-darisuku-pedalaman-mentawai-yangmulai-terkontaminasi/ 
